\title{
Kerrotun minän moninaisuus
}

\author{
Hynninen, Anna 2017: Minä, lotta, vaimo, äiti. Kerronnan variaatio ja toimijuus \\ aktiivikertojan muistelukerronnassa.
}

Turku: Turun yliopisto. 406 sivua.

\section{Eerika Koskinen-Koivisto}

\begin{abstract}
A nna Hynninen tutkii folkloristiikan väitöskirjassaan yhden aktiivikirjoittajan, Pyhäjärvellä syntyneen siirtokarjalaisen Toini Pelkosen, pitkän aikavälin kattavaa muistelukerrontaa näkökulmanaan kerronnan ja toimijuuden tilanteinen variaatio. Tutkimuksen tavoitteena on tuoda esille kerronnan tuottamisen ehtoja ja keinoja, joilla kertoja rakentaa elämänkertomustaan kokonaiseksi sekä nostaa samalla esiin kerronnassa ilmeneviä ristiriitaisuuksia ja säröjä. Toini on vastannut vuosina 1981-1996 lähes kaikkiin Museoviraston järjestämiin kyselyihin sekä Suomalaisen Kirjallisuuden Seuran keruisiin vuodesta 1981 alkaen. Hynninen luonnehtii arkistojen keruisiin osallistumisen olleen Toinille elämäntapa, mahdollisuus pohtia elämäntapahtumia ja sen eri puolia, sekä mahdollisuus toteuttaa itseään ja osallistua hänelle merkityksellisen perinteen kuten siirtokarjalaisen identiteetin määrittelyyn.
\end{abstract}

Hynnisen tutkimus on ensimmäinen yhden kirjoittajan tuottamaa kirjallista omaelämäkerrallista muisteluaineistoa käsittelevä tutkimus Suomessa. Se tuottaakin uutta tietoa aktiivikirjoittajan ja arkistoinstituution toiminnasta sekä kirjoitetun muisteluaineiston luonteesta ja sen tutkimisen mahdollisuuksista. Teksteihin painottuvan analyysin lisäksi Hynninen on tavannut Toinia useiden vuosien aikana ja nauhoittanut osan kohtaamisista. Ensimmäinen tapaaminen ajoittuu vuoteen 2003, jolloin Hynninen viimeisteli pro gradu -tutkielmaansa. Pitkäikäinen Toini sai todistaa myös Hynnisen väitöstutkimuksen valmistumista.

Hynninen on jakanut tutkimuksensa kahteen eri analyysiosaan. Ensimmäisessä osassa hän lähestyy omaelämäkerrallisen subjektin ja naiseuden rakentumista avoimissa valta- ja diskurssiverkostoissa intersektionaalisuuden näkökulmasta tarkastellen Toinin kerrottua naiseutta suhteessa muihin sosiaalisen erottelun kategorioihin ja pohtien, miten erojen suhteet muodostuvat. Hynninen asettaa Toinin kertomuksen myös suhteessa elämänvaiheisiin ja sosio-historialliseen kontekstiin. Toisessa analyysiosassa Hynninen keskittyy minän variaatioon yhdistäen performatiivisen ja positioanalyyttisen lähestymistavan. Hän paikantaa kerronnasta erilaisia subjektipositioita ja niiden mahdollisuuksia pohtien laajemmin kertojan ja kerronnan toimijuutta, jonka näkee toteutuvan kertojan valinnoissa erityisesti silloin, kun tämä päättää vaieta joistain asioista. 


\section{Metodologiset polut}

Hynnisen tutkimuksessa on vahva metodologinen painotus. Kuten kirjoittaja itsekin toteaa, tutkimuksessa sovellettavat menetelmät ja teoreettiset lähestymistavat ovat moninaiset. Niitä kuitenkin yhdistää selkeä metodologis-teoreettinen pohjavire. Hynnisen tutkimus paikantuu sosiaaliseen konstruktionismiin ja siihen kytkeytyviin diskurssi-, performatiivisuusja positiointiteorioihin, jotka painottavat kerronnan prosessuaalisuutta ja moninaisuutta. Monet näistä teorioista ovat peräisin feministisestä tutkimuksesta. Hynninen avaa teorioiden taustat ja käyttää käsitteitä taitavasti ja johdonmukaisesti. Hän myös rakentaa niistä toimivan välineistön oman aineistonsa tarkasteluun. Havainnollistaakseni tätä poimin muutaman esimerkin käsitteiden ja teorioiden soveltamisesta.

Hynninen esittelee ja soveltaa tutkimuksessaan feminististä omaelämäkertatutkimusta, josta on löytänyt välineitä sekä lukea Toinin kirjoittamia tekstejä että tulkita kohtaamisia hänen kanssaan. Molempien kohdalla Hynninen soveltaa affekteihin liittyviä teorioita ja käsitteitä. Hynninen on tehnyt kiinnostava menetelmällisen valinnan välttämällä varsinaisten haastattelujen tekemisen Toinin kanssa. Sen sijaan hän kutsuu kohtaamisiaan Toinin kanssa affektiiviseksi haasteluksi, joka tähtää täysin spontaaniin ja avoimeen vuorovaikutukseen. Haastelu on Toinin itsensä käyttämä sana. Affektiivisuus puolestaan viittaa erityisesti vuorovaikutuksen spontaaniuteen, keskusteluiden prosessuaalisuuteen ja luovuuteen. $\mathrm{Ne}$ mahdollistivat kerronnan ja kertomusten aukkoihin sekä aiemmin turhilta tai kielletyiltä tuntuneisiin asioihin tarttumisen.

Haasteluiden pohjalla onkin ajatus uutta luovasta ontologiasta, jota Hynninen kutsuu kerronnallisen tulemisen prosessiksi. Tulemisen ontologia on peräisin ranskalaisen filosofin Gilles Deleuzen ajattelusta. Siinä olemassaoloa ei ymmärretä vanhojen merkitysjärjestelmien ja normien toistona vaan jatkuvana tulemisena, moninaistumisena ja uuden tuottamisen liikkeenä. Hynninen lähestyykin kerrontaa ja muistamista toimintana, jossa ei etsitä valmiina olevia ja talletettuja asioita, vaan luodaan ja pohditaan, aktivoidaan menneisyydessä erilaisia mahdollisuuksia. Hynnisen sanoin "[m]uistelu ja haasteleminen ovat matkaamisia hylättyjen argumenttien luokse ja menneisyyden avaamista uusille kysymyksille. Näin myös käsityksemme menneisyydestä saattaa muuttua, se ei ole jotain mikä on yksinkertaisesti vain mennyt, vaan jotain joka on meissä alati läsnä" (s. 47).

Affektiivisessa haastelussa on tärkeä eettinen ulottuvuus: kerronnallisen tulemisen prosessi on jaettu ja yhteinen. Molemmat osapuolet, sekä tutkija että kertoja, ottavat avoimessa ja spontaanissa kohtaamisessa riskejä ja asettavat itsensä haavoittuvaan tilaan. Hynnisen mukaan "[a]ffektiivisuus on kykyä tuntea, vaikuttua ja tulla liikutetuksi. Onnistuessaan se tekee subjektista kestävämmän lisäten voimaa olla tulemisen tilassa" (s. 48).

Affektiivisuus on ohjannut myös Hynnisen luentaa, jossa hän on käyttänyt tietoisesti tunteita "lukureitteinä". Hynninen korostaa, että affektiivinen luenta, joka ottaa huomioon kohtaamisessa syntyvät tunteet ja niiden vaikutuksen merkitysten muodostumisessa, ei tarkoita samaa kuin feministisessä tutkimuksessa käytetty empaattinen luenta, jossa pyritään lähentymään kirjoittajaa ja ymmärtämään hänen kertomaansa. Hynninen ei usko, että tyhjentävä ymmärtäminen on mahdollista, vaan korostaa, että sen myöntäminen pysäyttää tutkijan pohtimaan omaa paikantumistaan ja uusien lähestymistapojen soveltamista. 
Empaattisen luennan sijaan Hynninen nojaa Marja Kaskisaaren (2000) kehittämään lukutapaan, joka tähtää ruumiin resonointiin korostaen lukijasubjektin ja kirjoittajasubjektin erillisyyttä. Hynnisen mukaan muisteluaineiston luenta on pääasiassa toiseuksien luentaa, jossa ruumiin resonoinnin kautta syntyy kokemus kerrotusta. Lukijan oma ruumis resonoi eri tavoin kuin kertojan tuottaen samalla merkityksenantoja ja mielikuvia, jotka heijastuvat toisiin ruumiisiin tehden näin luennasta kaksisuuntaisen prosessin. Uusmaterialistisesta feminismistä kumpuavat affektiteoriat tukevat Hynnisen tutkimuksen keskeisintä lähestymistapaa eli kerronnan performatiivisuutta korostaen omaelämäkerrallisen muistelukerronnan vastavuoroisuutta ja subjektien kohtaamista. Itse analyysissä tämä näkyy sekä eettisenä asenteena että syvyytenä ja herkkyytenä.

\section{Analyysin painotukset ja anti}

Kuten tutkimuksen otsikko osoittaa, Hynninen on nostanut tutkimuksessaan esiin Toinin muistelukerronnassa esiintyvät moninaiset ja hänelle merkitykselliset identiteetit. Tutkimuksen ensimmäisessä analyysiosassa Hynninen on tarkastellut Toinin muistelukerrontaa suhteessa erilaisiin naiseutta määrittäviin kategorioihin soveltaen teoriaa intersektionaalisuudesta, joka korostaa identiteetin käsittämistä ennen kaikkea suhteisuudeksi ja positioitumiseksi. Hynnisen mukaan kerrontaa voi lähestyä sosiaalisiin kategorioihin asettumisen ja asetetuksi joutumisena, eräänlaisena kaksoisliikkeenä, joka on tärkeä osa inhimillistä toimijuutta.

Naiseuden ja siihen liittyvien erojen analyysissä Hynninen on soveltanut temaattista ja elämäkerrallista luentaa eli muodostanut kertojan kerronnallisen elämänkaaren ja eritellyt kronologisten elämänvaiheiden keskeiset teemat. Usean kontekstualisoivan lukukerran jälkeen Toinin kerronnassa merkittävimmiksi naiseuden suhteiksi hahmottuivat kansalaisuus, lottuus, vaimous ja äitiys. Maalaisympäristössä lapsuuden työt ja koulutus olivat sukupuolittuneita ja normatiivisia. Kirjoittaminen näyttäytyi Toinille lapsuudesta saakka tärkeänä vastapainona ja itsenäisyytenä, mitä hän piti tärkeänä myös myöhemmissä elämänvaiheissa. Muihin itsetuntoa ja omanarvontuntoa kohottaviin kokemuksiin lukeutui toimiminen lottana sota-aikana, mikä tarjosi nuorelle Toinille arvostusta ja paremman luokka-aseman kuin evakoiden osaksi muuten olisi koitunut. Avioliitto ja vaimous merkitsivät Toini paitsi toveruutta ja ydinperheideologian mukaista ihannetta myös mahdollisuutta toimia isänmaallisesti kasvattaen uusia kunnon kansalaisia. Kuuden lapsen äiti kohtasi elämänsä aikana myös äitiyden ideaalin muuttumisen kotiäidistä kohti ansioäitiä, ja koki sen suhteen arvostuksen puutetta.

Toisessa analyysiosiossa, jossa Hynninen tarkastelee avainkertomuksia ja niiden variaatiota, korostuu kerronnan hahmottuminen suhteessa ajallisuuteen ja kerrontahetkeen. Hynninen määrittelee avainkertomuksen toistuvaksi ja varioivaksi kertojan maailmankuvaa, elämää ja identiteettiä määrittäväksi kertomukseksi. Hän on valikoinut aineistoonsa kuusi avainkertomusta, joista osa sijoittui selkeästi johonkin Toinin elämän taitekohtaan, ja toiset taas joko yksittäiseen lyhyeen aikaväliin tai pidempään ajanjaksoon. Avainkertomusten varianttien tarkastelu rinnakkain episodi episodilta on havainnollista ja avaa lukijalle mahdollisuuden seurata Hynnisen positioanalyysia ja toisaalta tehdä omia tulkintoja ja oivalluksia. Pidänkin tärkeänä Hynnisen havaintoa siitä, että vaikka tietty kirjallinen teksti on näennäisesti pysyvä ja muuttumaton, on sen luenta ja tulkinta aina tilannekohtaista. Kuten Hynninen toteaa: "saman tekstin eriaikainen luenta voi nostaa tekstistä esiin aivan uudenlaisia merkityksiä" (s. 260). Siksi 
lähilukuun kuuluva toistuva luenta on tärkeää, ja yhtä tärkeää on artikuloida, miten useaan kertaan lukiessa tekstin tulkinnan mahdollisuudet lisääntyvät ja muuttuvat - kuten Hynninen tutkimuksessaan osoittaa.

\section{Lopuksi}

Erilaisten teoreettisten pohdintojen tarkkuuden ja yhteen nivomisen tuloksena Hynninen on kehittänyt tutkimuksessaan uusia käsitteitä ja analyysivälineitä, joita voi jatkossa soveltaa niin omaelämäkerrallisten tekstien ja muistelun kuin suullisen kerronnan tutkimiseen. Pohdinnat kerronnan kontekstuaalisuudesta ja ajallisuudesta ulottuvat syvälle minän ja olemassaolon ontologiaan. Analyysin tulokset kuten esimerkiksi intersektionaalisten suhteiden luenta havainnollistuu sekä kerronnan sisällön että ilmaisun tasolla. Hynnisen tutkimus ei tyhjene yhdellä lukukerralla, kuten ei Toinin omaelämäkerrallinen muistelukerrontakaan.

\section{Kirjallisuus}

Kaskisaari, Marja 2000. Kyseenalaiset subjektit. Tutkimuksia omaelämänkerroista, heterojärjestyksestä ja performatiivisuudesta. Jyväskylä: Jyväskylän yliopisto: Kampus kirja.

Filosofian tohtori Eerika Koskinen-Koivisto työskentelee Jyväskylän yliopistossa ja tutki väitöskirjassaan Elsa Koskisen (s. 1927) suullista elämänkerrontaa. 